Karabowicz, Tadeusz, i Jaruczyk, Wiktor. «Literatura ukraińska na Podlasiu: od gwary do języka literackiego». Лінгвостилістичні студії, вип. 12, 2020, с. 83-96.

Karabowicz, Tadeusz, and Iaruchyk, Viktor. "Ukrainian Literature in Podlasie: from Dialect to Literary Language". Linguostylistic Studies, iss. 12, 2020, pp. 83-96.

УДК 821.161.2(438)(082.21)

https://doi.org/10.29038/2413-0923-2020-12-83-96

\title{
LITERATURA UKRAIŃSKA NA PODLASIU: OD GWARY DO JĘZYKA LITERACKIEGO
}

\author{
Tadeusz Karabowicz \\ Uniwersytet Marii Curie-Skłodowskiej w Lublinie, \\ Lublin, Polska \\ Wiktor Jaruczyk \\ Wschodnioeuropejski Uniwersytet Narodowy im. Łesi Ukrainki, \\ Łuck, Ukraina
}

Artykuł porusza problemy dzieł poetyckich pisarzy mówiących po ukraińsku na Podlasiu. Autorzy próbowali przeanalizować twórczość pisarzy, którzy w swoim poetyckim języku posługiwali się gwarami swoich rodzinnych miejscowości w drugiej połowie XX wieku. Główny nacisk robiony jest na nowe imiona w dyskursie literackim oraz problemach ich prac. Autorzy próbują przeanalizować cechy poezji, z której korzystają z różnych powodów osoby mieszkające poza Ukrainą kontynentalną.

Ключові слова: literatura, poezja, Podlasie, proces literacki, Ukraiński dialekt, język literacki, cechy dialektu.

Карабович Тадеуш, Яручик Віктор. Українська література на Підляшші: від говірки до літературної мови. У статті актуалізовано проблему переходу українських митців від мови рідних говірок до літературної мови. Дебютувавши у формі говіркових традицій, письменники Підляшшя удосконалювали не тільки форму своїх творів, але й намагалися приєднатися до українського літературного дискурсу. Вони відточували мовну майстерність, причому не всім вдалося подолати діалектні впливи. Основна увага зосереджена на нових іменах в літературному процесі і проблематиці їхньої творчості. Автори роблять спробу проаналізувати особливості віршування, якими користуються автори, котрі з різних причин живуть за межами материкової України.

Ключові слова: література, поезія, Підляшшя, літературний процес, українська говірка, літературна мова, діалектні особливості.

\section{UKRAINIAN LITERATURE IN PODLASIE: FROM DIALECT TO LITERARY LANGUAGE Tadeusz Karabowicz \\ Maria Curie-Skłodowska University, Lublin, Poland Viktor Iaruchyk}

Lesya Ukrainka Eastern European National University, Lutsk, Ukraine

(C) Karabowicz, T., i Jaruczyk, W., Східноєвропейський національний університет імені Лесі Українки, 2020. Це стаття відкритого доступу на умовах СC BY-NC 4.0 
The article highlights the issue of the Ukrainian authors' transition from the language of native dialects to the literary language. Having debuted in the spoken tradition discourse, Podlasie writers not only improved the form of their works but also tried to join the Ukrainian literary discourse. They honed their language skills, and not all of them managed to overcome the dialectal influences. The creative work of Ivan Kyryzyuk, Yuri Gavryluk, Yevhenia Zhabinska, Sofia Sachko and other representatives of Northern Podlasie was studied. The authors of the article lay emphasis mainly on the works created in the second half of the twentieth century. The main focus is on new names in the literary process and the problems of their work. The authors try to analyze the features of poetry by authors who, for various reasons, live outside mainland Ukraine.

When discussing the phenomenon of the Ukrainian literature in Podlasie, we have to assume that it has witnessed a significant transformation of consciousness, from the Ukrainian-Belarusian borderland dialect (1970s) to its native Ukrainian language version after 1990. It concerns the works of Ivan Kyryzyuk, Yuri Havryliuk, and Yevhenia Zhabinska, in particular. At the same time, for such literary figures as Sofia Sachko or Yustyna Korolko, the classification into Ukrainian or Belarusian literature remains problematic. It would be optimal to state that both poets are part of the niche literary discourse undertaken by the Ukrainian dialect of Bielsk Podlaski.

Key words: literature, poetry, Podlasie, literary process, Ukrainian dialect, literary language, dialect peculiarities.

Wstęp. Literackie środowisko ukraińskie z Podlasia piszące na progu swojego debiutu gwarą ukraińską i uważające się od połowy lat osiemdziesiątych XX wieku za część składową ukraińskich struktur społecznokulturalnych, nie od razu było świadome swojej ukraińskiej przynależności narodowej. Nie deklarowało także swojej przynależności do Ukraińców w Polsce, jako mniejszości narodowej. Drogę tę wyznaczyły wielorakie regionalne przeszeregowania, zwłaszcza religijna świadomość prawosławna i działające na Podlasiu, od 1956 roku Białoruskie Towarzystwo Społeczno-Kulturalne (BTSK). Jego organem prasowym pozostawała „Niwa”, tygodnik ukazujący się w języku białoruskim oraz powołana przez Zarząd Główny BTSK organizacja literacka „Białowieża”, grupująca poetów i pisarzy regionu. W „Niwie” drukowano wiersze, tłumaczenia, felietony, humoreski oraz prozę. W „Białowieży” odbywały się spotkania literackie, dające przepustkę nie tylko do druku w białoruskojęzycznej prasie BTSK, ale także członkowstwo w Związku Literatów Polskich. W latach sześćdziesiątych możliwości druku własnych utworów poszerzyły się o „Kalendarz Białoruski” oraz indywidualne tomiki wierszy. W dekadzie lat siedemdziesiątych i osiemdziesiątych, Białowieżanie publikowali się w Mińsku na Białorusi, a także ich utwory tłumaczono na język polski.

W grupie tej związanej z „Białowieżą” i tygodnikiem „Niwa”, byli także poeci i pisarze którzy posługiwali się ukraińską gwarą podlaską wyniesioną z domu rodzinnego, nie znali bowiem literackiego języka białoruskiego. Swoje utwory do „Niwy” nadsyłali po ukraińsku, czy jak się tutaj na Podlasiu mówiło po 1945 roku „mową prostą" lub „po swojemu”. Byli to poeta Iwan Kyryziuk, urodzony w 1949 roku, (w języku ukraińskim: Іван Киризюк), debiutujący w „Niwie” po 1970 roku i poetka Sofija Saczko, urodzona w 1955 roku, (w języku ukraińskim: Софія, także: Зося, Зоя Сачко). Redakcja „Niwy” drukowała 
nadsyłane teksty, najczęściej gwarowe, w zapisie językowym białoruskim. Natomiast pewną trudność sprawiało redakcji zapisanie imion oraz nazwisk poetów piszących gwarą, dlatego też imię i nazwisko Iwana Kyryziuka zostało zapisane w kilku wersjach językowych: „Wania Kiryziuk”, „Iwan Kiryziuk” „Janka Kiryzjuk" (w języku białoruskim: Янка, Іван, Ваня Кіризюк), natomiast nazwisko Sofiji Saczko, (oficjalnie w dokumentach urzędowych: Zofia Saczko), jako Zosia Saczko, (w języku białoruskim: Зося Сачко).

Problemami językowymi wierszy ukraińskich pisarzy na Podlasiu zajmowali się Ołena Duć-Fajfer w artykule p.t. „Twórczość literacka Ukraińsców w Polsce po Drugiej Wojnie Światowej" (Дуць-Файфер), Teresa Zaniewska w swojej pracy p.t. „Podróż daremna. Szkice o poezji białoruskojęzycznej w Polsce”, Doroteusz Sawicki w artykule „Grabarka. Monaster na Świętej Górze”. Analizie językoznawczych osobliwości poezji ukraińskich pisarzy w Polsce poświęcali swoje artykuły Michał Łesiów, Tadeusz Karabowicz. Same teksty poetyckie badanych pisarzy naczęściej okazywały się na łamach rocznika „Ukraiński Zaułek Literacki" w Lublinie, również sporo badanych tekstów braliśmy $\mathrm{w}$ zbiorze p.t. Wołanie serca. Antologia poezji ukraińskiej Podlasia, wybór i przekład spełnił Jan Leończuk.

Cele badań. Celami naszych badań są osobliwości wykorzystania form gwarowych w utworach poetów, którzy tworzyli własną twórczość na terenach Białowieży i należeli do grup etnicznych ukraińskiej i białoruskiej. Poświęcając temu problemowi uwagę, językoznawca Michał Łesiów pisał, iż gwara w jakim areale czy tyglu narodowym by nie występowała, zawsze wskazuje pośrednią przynależność do danego narodu czy kultury (Лесів, „Мова” 20) ${ }^{1}$. Моże ona wyznaczać także bezpośrednie koordynaty w przypadku przynależności religijnej. Dla Podlasia był to problem bardziej skomplikowany, bowiem deklarująca swoją przynależność do prawosławia społeczność mieszkająca na Podlasiu niekoniecznie uważała się za Białorusinów czy Ukraińców.

Materiał i metody badawcze. Obiektem obecnych badań stały językoznawcze osobliwości twórczości ukraińskojęzycznych pisarzy na terytorium Poldlasia. Taka praca pomoże wyznaczyć rozwój języka utworów od gwary do języka literackiego. Stanie również pomocą do następnych badań mało znanych autorów. Dla osiągnięcia postawionego celu przeważnie wykorzystywaliśmy metodę analizy porównawczej wierszy napisanych gwarą i językiem literackim. Podejście lingwostylistyczne połączyliśmy z ogólną metodą

\footnotetext{
1 Підляські говірки становили мовну основу віршів таких відомих поетів, що походили і походять 3 Підляшшя, як Микола Янчук, Степан Сидорук, Іван Киризюк, Юрій Гаврилюк та багато інших, особливо у 2-ій половині XX століття. До цієї групи «підляських» поетів належить також Софія (Зося, Зоя) Сачко, народжена 1955 року у селі Вілька коло Більська-Підляського, авторка кількох збірок поезій, писаних, як правило, говіркою рідного свого села, а саме Пошукі (1982), Над днём похіляна (1991), Ще одна весна (1995) та Поеми (2000). Ці збірники видавало білоруське Літературне об'єднання «Бєлавєжа» 3 використанням засобів сучасної білоруської орфографічної системи. У 1983 - 1988 рр. частина віршів Софії Сачко, була друкована у 6 чергових випусках Збірника неформального Поетичного об’єднання «Наш голос», «Підляшшя» на правах рукопису, про що у 2008 році згадав Т. Карабович, а до передруку її поезій звідти на сторінках «Українського літературного провулка» вибрав А. Скатеринчук. У цих виданнях до графічної форми поезій С. Сачко використано засоби сучасної української орфографічної системи. Szerzej na ten temat: M. Łesiów, Мова віршів підляської поетеси Софії Сачко [Artykuł przygotowany dodruku do: „Український літературний провулок”, t. 12, Люблин 2012, s. 20.]
} 
interpretacyjno-kulturologiczną, dzięki czemu jest możliwe rozeznanie indywidualnego stylu poetów i stopnia ich adaptacji do realiów ukraińskojęzycznych. Metoda obserwacyjna pomogła w rejestracji określonych faktów i ujmowanie ich we wzajemnych związkach i zależnościach. Zgromadzone $\mathrm{w}$ artykule dane zostały poddawane interpretacji jako zjawisku oddziałującym na elementy i procesy danego systemu czy też określonej struktury organizacyjnej.

Wyniki badań i dyskusja. Poeta Iwan Kyryziuk piszący we wczesnej fazie twórczości gwarą ukraińską lecz drukujący w „Niwie” na początku lat siedemdziesiątych, nie uważał się za Białorusina, chociaż oficjalnie nie deklarował swojej narodowej przynależności jako ukraińskiej. Dopiero wyjazd w Bieszczady, do Komańczy, gdzie pracował w firmie budowlanej, sprawił oficjalną deklarację w stronę przynależności do narodu ukraińskiego i próbę druku swoich utworów w ukraińskim tygodniku „Nasze Słowo”, po 1980 roku oraz w roczniku „Ukraiński Kalendarz”, a następnie już w latach dziewięćdziesiątych w wydawnictwach literackich na Ukrainie.

Poetka Sofija Saczko, mimo studiów odbytych na filologii rosyjskiej w Uniwersytecie Marii Curie-Skłodowskiej w Lublinie, bezpośrednio nie deklarowała swojej ukraińskiej przynależności narodowej. Drukowała wiersze w latach osiemdziesiątych $\mathrm{w}$ białoruskojęzycznej prasie społeczno-kulturalnej, jak również w ukraińskim tygodniku "Nasze Słowo". Poetka pozostawała prawosławną ze wsi Wólka pod Bielskiem Podlaskim, odwołując się do religijnej przestrzeni rodowodu wypowiedzianego chociażby w debiutanckim wierszu Weczór kapusty. Nie pozostaje tajemnicą fakt, że w tomiku Poszuki (Пошукi), Sofiji Saczko z 1982 roku wiersze białoruskojęzyczne przetłumaczył redaktor zbiorku, poeta Aleś Barski (Aleksander Barszczewski), pozostawiając drugą część tomiku w oryginale, czyli w ukraińskiej wersji gwarowej.

Dorobek poetycki Sofiji Saczko, pozostaje przykładem literackiego pogranicza ukraińsko-białoruskiego, natomiast gwarowa forma utworów, w obu literaturach, ukraińskiej i białoruskiej, była (będzie) traktowana jako twórczość niszowa.

W latach osiemdziesiątych Zarząd Główny Ukraińskiego Towarzystwa Społeczno-Kulturalnego (UTSK), wydał dwa tomiki wierszy podlaskich poetów, Stepana Sydoruka, Nad Buhom (ukraińska nazwa: Над Бугом) w 1982 roku ze wstępem Michała Łesiowa oraz Iwana Kyryziuka, Mojij Batkiwszczyni (ukraińska nazwa: Моїй Батьківщині) w 1986 roku.

Druk w 1982 roku, tomiku poety ludowego ze Stawek pod Włodawą, Stepana Sydoruka, piszącego gwarą ukraińską, był możliwy dzięki zmianom w Polsce po 1980 roku, które były związane z powstaniem Solidarności i demonstracjami politycznymi. Wówczas także, odbyły się debiuty młodych $\mathrm{w}$ tygodniku ukraińskim „Nasze Słowo”, poety Tadeja Karabowycza (Тадея Карабовича), poetki Jarosławy Chrunyk (Ярослави Хруник), i autora prozy poetyckiej, Romana Kryka (Романа Крика). 
W tej grupie za sprawą redaktora Romana Gałana, debiutowali również poeci z Podlasia w specjalnej rubryce „Naszego Słowa” o nazwie „Literaturna Storinka". Byli to Iwan Kyryziuk, Jurij Hawryluk, Jurij Traczuk i Jewhenija Żabińska. Wierszami gwarowymi debiutowała w „Naszym Słowie” także Sofija Saczko. Charakterystyczną tematyką tych debiutów było Podlasie jako mała ojczyzna, (wiersz Jurija Hawryluka Mowo ridna) a także liryka osobista.

Natomiast druk tomiku Iwana Kyryziuka w 1986 roku, w wydawnictwie UTSK w Warszawie, otwierał szersze możliwości prezentacji ukraińskiej literatury Podlasia, wśród ukraińskich czytelników w Polsce i na Ukrainie. Świadczą o tym wielokrotne publikacje w „Ukraińskich Kalendarzach” oraz w miesięcznym dodatku do „Naszego Słowa”, „Naszej Kulturze”.

W latach 1983-1988, w Lublinie i Bielsku Podlaskim ukazywał się rocznik literacki, na prawach rękopisu, faktycznie jako wydawnictwo drugiego obiegu, o nazwie „Nasz Hołos” (ukraińska nazwa: „Наш голос”). Redaktorami rocznika byli poeta i zbieracz folkloru ukraińskiego na Południowym Podlasiu, Iwan Ihnatiuk (Іван Ігнатюк) oraz poeta Iwan Kyryziuk. W początkowej fazie wydawania „Naszego Hołosu”, na jego szpaltach publikowano wiersze pisane gwarą ukraińską, by następnie przejść do druku utworów w ukraińskim języku literackim. Autorami sześciu tomów rocznika byli: Iwan Kyryziyk, Iwan Ihnatiuk, Stepan Sydoruk, Sofija Saczko, Jurij Hawryluk, Jewhenija OwsianiukMartyniuk, Jewhenija (Żenia) Żabińska, Iryna Borowyk, Petro Kyryziuk (brat Iwana Kyryziuka), Hanna Pasicznyk, Iwan Chwaszczewski, Jurij Bajena, Olha Pidlaszanka (osoba piszące pod pseudonimem), Stepan Troć i Jurij Traczuk.

Niektórzy autorzy „Naszego Hołosu”, drukowali się paralelnie w „Naszym Słowie", tak jak Sofija Saczko czy Jurij Traczuk, co nie oznacza ich świadomej deklaracji do ukraińskiej przynależności narodowej. Poeta Jurij Bajena, po epizodzie publikacji swoich utworów w „Naszym Hołosie”, powrócił do białoruskiego środowiska literackiego. Większość autorów rocznika, jako młodych debiutantów, pochłonęła praca społeczna na rzecz swojego środowiska i faktycznie przestali pisać.

Okres lat osiemdziesiątych był w Polsce nacechowany istotnymi zmianami społeczno-politycznymi, mimo obecności stanu wojennego oraz istnienia cenzury, co nie sprzyjało rozwojowi mniejszości narodowych i pogłębianiu ich aspiracji religijnych i kulturalno-literackich.

W 1990 roku po upadku systemu totalitarnego w Polsce, przestała również instytucjonalnie obowiązywać cenzura. Na Podlasiu powołano w miejsce UTSK, organizację społeczno-kulturalną o nazwie Związek Ukraińców Podlasia: Союз українців Підляшшя (СУП), z siedzibą w Bielsku Podlaskim. Organem prasowym nowej organizacji był kwartalnik „Nad Buhom i Narwoju” („Над Бугом і Нарвою”), który zaczął ukazywać się w Bielsku Podlaskim. Do pracy redaktorskiej włączył się wówczas Iwan Kyryziuk, którego wiersze zaczęły stanowić integralną część kwartalnika oraz Jurij Hawryluk drukujący w „Nad Buhom i Narwoju” własne teksty publicystyczne, poezję oraz dziennik literacki. 
Po 1990 roku podlaskie ukraińskie środowisko pisarskie, dokonało świadomego wyboru i niespotykanej integracji z literaturą ukraińską nad Dnieprem. Utwory poetyckie drukowano w języku literackim w czasopismach literackich w Kijowie, Charkowie oraz we Lwowie. Publikowano również poezji gwarą podlaską jak również $\mathrm{w}$ języku literackim $\mathrm{w}$ miesięczniku literackim na Słowacji „Dukla”, a także w ukazującym się w Nowym Jorku kwartalniku artystyczno-literackim „Swito-Wyd”. Poeci podlascy od 2001 roku zaczęli publikować swoje utwory $\mathrm{w}$ prasie literackiej ukazującej się $\mathrm{w}$ języku ukraińskim w Polsce, roczniku „Ukraiński Zaułek Literacki” (2001-2011), „Almanachu Ukraińskim” oraz innych. W 2003 roku do Związku Pisarzy Ukrainy zostali przyjęci Iwan Kyryziuk, Jewhenija Żabińska oraz Jurij Hawryluk. W 2008 roku Iwan Kyryziuk otrzymał od prezydenta Ukrainy Wiktora Juszczenki medal „Za Zasłuhy” jako szczególne wyróżnienie za dokonania literackie i działalność społeczną. W latach 1990-2011 Iwan Kyryziuk, Jurij Hawryluk, Jewhenija Żabińska i Jurij Traczuk wydawali własne tomiki wierszy oraz doczekali się tłumaczeń swojej twórczości na języki obce. W 2008 roku ukazała się antologia poezji ukraińskiej Podlasia Wołanie serca w wyborze i tłumaczeniu na język polski poety Jana Leończuka.

Twórczość Iwana Kyryziuka (rok urodzenia 1949), można podzielić na dwa etapy, pierwszy gwarowy, prezentowany od 1973 roku przez poetę $w$ białoruskojęzycznej „Niwie” oraz drugi, powstający po 1980 roku w ukraińskim języku literackim i drukowany w prasie ukraińskiej. Oba te okresy spina klamra poetyckiego zamyślenia nad własną twórczością i życiem. Z tego punktu widzenia należy uznać twórczość Iwana Kyryziuka za zjawisko ciekawe. Jak pisał Jan Leończuk: „Różne wszak były drogi w odnajdywaniu języka ukraińskiego. Wielu $\mathrm{z}$ poetów rozpoczynało twórczą pasję $\mathrm{w}$ dialekcie ukraińskim lub białoruskim, publikując na łamach gościnnej prasy białoruskiej" (Wołanie serca).

Iwan Kyryziuk w swojej twórczości łączył różne kręgi tematyczne w jedną całość, nadając wierszom spójnej funkcji ekspresyjnej oraz wieloznaczności leksykalnej:

Wieczorne modły

Dogasają ikonami

Dobrych nadziei

Nie oczekuję rozgrzeszenia

Odczuwam jedynie Piętno

Które nie ma granic

Dzielących mnie od ciebie

Wiesz dobrze -

Że tylko zdrada

Okrada życie z tajemnic

(przekład Jan Leończuk) (Wołanie serca 147). 
Twórczość Iwana Kyryziuka tkwiła w gęstej sieci literackich i kulturowych odniesień do rzeczywistości zewnętrznej. Ulubionym motywem poety pozostawała historia Podlasia z bizantyjskimi konotacjami oraz cerkiewną duchowością. To tutaj w Bielsku Podlaskim doświadczeniem poety pozostawała historia, kultura i prywatność. Autor będąc wierny sobie, jednocześnie czuł się rozbitkiem wzmocnionym wiarą w miłość i jej życiodajne soki. Własne istnienie poeta widział $\mathrm{w}$ opozycji do myślenia mitycznego, przekazując tym samym fundamentalne pytania o ciągle tworzącym się świecie. We wczesnym okresie twórczości Iwan Kyryziuk fascynował się przyrodą, lubił ją opisywać w utworach, które przypominały miniatury poetyckie. Jednocześnie doświadczenie literackie poety zmieniało się, autor otwierał się na tematy ogólnoludzkie, pisał o Podlasiu jako o Arkadii serca, zanurzał się w historii oraz dniu dzisiejszym swojego narodu.

\author{
Przodków pieśni \\ O chwale kozackiej \\ Uparcie brzęczą \\ Struną \\ Wyszczerbionej szabli \\ (przekład Jan Leończuk) (Wołanie serca 58).
}

Te pytania świadczące o głębokim zamyśleniu poety nad ziemią rodzinną, Iwan Kyryziuk stawiał samemu sobie, jako rodzaj wewnętrznej kontemplacji. Były one myślą przewodnią jego wielu utworów napisanych pod wpływem głębokich przemyśleń nad problemem ojcowizny i małej ojczyzny. Poeta zawsze powracał do semantycznej metafory, gdzie bohaterem lirycznym jest „smak chwili" udomowiony myślą, by spełniało się życie w jego ponadczasowym wymiarze oraz by trwała wieczność z jej porami roku, datami oraz intymnością.

Pod dłonią odczuwam

Ciepło twojego ciała

I wówczas bez krzyku

Odlatuje

Oswojony już strach

Chcąc jak gdyby oddzielić

Smak tych chwil

Od zapachu wieczności

... (przekład Jan Leończuk) (Wołanie serca 51).

Twórczość Iwana Kyryziuka pozostawała wierna filozoficznym rozmyślaniom oraz poszukiwaniom trwałych wartości. Zaduma nad światem i próba zrozumienia jego praw to tylko niektóre wyznaczniki, wciąż obecne $\mathrm{w}$ utworach poety. Powracają one cyklicznie, być może podświadomie, do nowych wierszy i sprawiają wrażenie, że poeta pisze ciągle ten sam tekst, nadając słowom i sformułowaniom poetyckim nowego znaczenia.

Różnorodność tematyczna utworów Iwana Kyryziuka sprawia, że twórczość poety jest rozpoznawalna na tle ukraińskiej poezji Podlasia. Tworzy 
ona swoistą polifonię i niesie duży ładunek emocjonalny oraz bogactwo myślowe. Iwan Kyryziuk fascynuje się także folklorem, który stanowi dopełnienie świata poetyckiego oraz odwołuje poezję autora do pogranicza ludowego.

Twórczość Sofiji Saczko (rok urodzenia 1955) (Zaniewska), mimo, że powstawała $\mathrm{w}$ archaicznym dialekcie wyniesionym $\mathrm{z}$ rodzinnej Wólki koło Bielska Podlaskiego nie należała do poezji ludowej. Rozważania egzystencjalnofilozoficzne poetka wyrażała współczesnymi środkami stylistycznymi zaczerpniętymi z ulubionych lektur. Były to jej fascynacje literackie z młodości i ze studiów, opowiadania Fiodora Dostojewskiego, wiersze Tadeusza Nowaka oraz twórczość awarskiego poety Rasuła Gamzatowa. Tematyka wierszy świadczyła o silnym poczuciu wspólnoty językowej i religijnej oraz emocjonalnej więzi z miejscem urodzenia. Strony rodzinne zatarte nostalgią (Sofija Saczko po ukończeniu studiów zamieszkała w Bielsku Podlaskim), autorka opisywała poprzez zapamiętane szczegóły oraz sytuacje rodzinne. Debiutowała wierszem Weczur kapusty, który przyniósł jej rozgłos w środowisku czytelniczym „Niwy”, bowiem w utworze tym autorka zawarła obrzęd kiszenia kapusty a szerzej pamięć kulinarną i trwanie zbiorowości plemiennej w ustalonym rustykalnym rytuale:

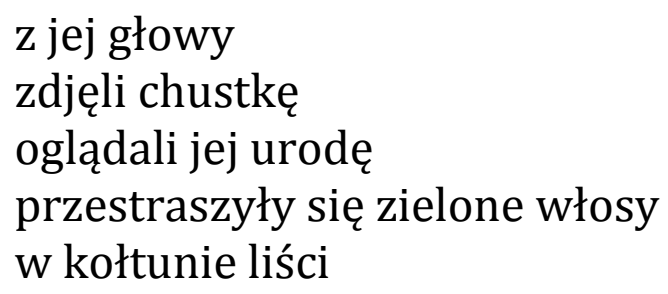

ludzie ostrzyli słowa - noże wyostrzali słowa - metale (jeszcze nierozumnie)

ręka niedbale na deskę ją rzuciła i

przeobraziła się łzami zielonymi zapłakała ... (przekład Wiktor Szwed) (Wołanie serca 97-98).

W poezji Sofiji Saczko zaznaczył się silny pierwiastek emocjonalny, jej związki ze znajomym krajobrazem i utrudzonymi pracą na roli współmieszkańcami. Mimo, że poetka nie była autorką opisów przyrody, jej wiersze tętnią porami roku, zapachem pieczonego $w$ wiejskich piecach chleba oraz słychać w nich pieśni śpiewane $w$ jej rodzinnym domu, przy tym aktywnie wykorzystuje formę gwarową. W utworach Sofiji Saczko zaznaczone są wątki baśniowe oraz symetria narracyjna. „Elementy ojczystego krajobrazu nie są tłem ani dekoracją - jak pisała o twórczości poetki Teresa Zaniewska, lecz stanowią 
sposób oraz formę wyrażania skomplikowanych spraw i uczuć ludzkich") (Zaniewska 71).

Swojej poezji Sofija Saczko nie adresowała do mieszkańców rodzinnych stron, chociaż pragnęła by jej wiersze zbłądziły pod podlaskie strzechy. Poruszała bowiem tematy bliskie jej sercu, a często dalekie dla ludzi ciężko pracujących na roli. Mówiła o determinacji wewnętrznej wobec wyzwań cywilizacyjnych oraz szukała przeciwdziałania na samotność w modlitwie i rozmowach z drugim człowiekiem. Stąd w jej wierszach występował symbol wiejskiej przydrożnej ławki, jako archetyp spotkania i rozmowy, widziany przez pryzmat uniwersalnego rozmyślania nad życiem. Jak pisała Teresa Zaniewska: „Bohaterka wierszy Zosi Saczko zmaga się z czasem, szuka swego miejsca w jego „wielkim kołowrocie”. Przeżywa bolesną świadomość, iż nie powstrzyma biegu godzin, szuka wiec miary człowieka w nim samym" (Zaniewska 96).

Poetka z tematyki wiejskiej zaczerpnęła utrwalone tradycją symbole, wierzenia oraz umiejętność łączenia potoczności $\mathrm{z}$ sacrum. W progach cerkiewnych widziała ekstazę pocieszenia i natchnienie dla własnej poezji. Ten typ potoczystości zaowocował świeżymi obrazami poetyckimi oraz przekonywująco wpłynął na widzenie świata przez autorkę.

czas już czas

do ciepłych krajów

żal serca i kaliny

w makatkę by zaszyć

grządki pozłacane brzozami czytać

cicho słuchać

mniej widzieć

w skrzynie upychali

- myszy zjadły

cieszmy się - może jeszcze zdążymy

przed dwunastą

(przekład Jan Leończuk) (Wołanie serca 95).

Twórczość ukraińskiej poetki rozwijająca się $\mathrm{w}$ formie wierszy gwarowych, była oceniana jak fenomen pogranicza, stąd utarło się przekonanie, że jest to poetka należąca jednocześnie do kultury białoruskiej i ukraińskiej, Poeta Aleś Barski we wstępie do tomiku Poszuki z 1982 roku, napisał nawet, że tożsamości literackiej Sofiji Saczko należy szukać w poezji polskiej, poprzez wyrażanie systemu wersyfikacyjnego kluczem bezrymowym (Zaniewska 97).

Fenomen twórczy Sofija Saczko przekazała swojej córce Justynie Korolko, której poświęciła szereg wierszy gwarowych o nazwie Wiersze dla Justynki, pozostające jedynym śladem poezji dla dzieci w literaturze Ukraińców Podlasia. 
Poezja Jurija Hawryluka (rok urodzenia 1964), rozwijała się na tle lat osiemdziesiątych dwutorowo, jako ukraińska poezja gwarowa i jako twórczość pisana w ukraińskim języku literackim. Poeta próbował również innych form twórczości, wypowiadając się, jako historyk (ukończył studia historyczne na Uniwersytecie Jagiellońskim w Krakowie), publicysta, kronikarz dnia codziennego (pisał dziennik o nazwie Chronologion) i literaturoznawca (zajmował się twórczością ukraińskiego poety z Łemkowszczyzny Bohdana Ihora Antonycza). Gdy zaczął ukazywać się kwartalnik Związku Ukraińców Podlasia „Nad Buhom i Narwoju”, poeta został powołany na stanowisko redaktora naczelnego tego pisma, co sprawiło, że kreował ideowo jego treść literacką. W poezji pozostawał jednakże wierny autentycznemu natchnieniu, stąd jego wypowiedzi literackie mają często indywidualne konotacje i odwołują się do motywów osobistych.

W świecie poetyckim Jurija Hawryluka życie ludzkie podlegało ciągłym przemianom, takie są bowiem prawa natury i tor zmieniającej się rzeczywistości. Poeta odczuwał „dotknięcia czasu”, jako coś nadzwyczaj bolesnego, dlatego też pragnął zatrzymać jak najwięcej wspomnień $\mathrm{z}$ dzieciństwa, które nazywał „ułomkami chwil”, bowiem one przypominały mu sny i marzenia. Wielowymiarowość tych doznań przekładała się $\mathrm{w}$ utworach poety na poszukiwanie sensu życia $\mathrm{w}$ słowie oraz jego wielowymiarowych konotacjach.

Poeta przywoływał wyraziste elementy wspomnień i pragnął by one „działy się" znowu w jego życiu oraz stawały się realną tkanką istnienia. W głosach z przeszłości, i Jurij Hawryluk rozpoznawał siebie i tęsknił za pełnią utraconego „wczorajszego zapodziania się” gdzieś ku ścieżkom „wśród najgłębszej ciszy gwiazd". To przesłanie pieczętował pragnieniem życia i widzeniem siebie jakby z góry lub z głębi serca.

W poezji Jewheniji Żabińskiej (rok urodzenia 1966), tradycja literacka oscylowała wokół toposu ojcowizny, szczęśliwych chwil dzieciństwa, miłości oraz rodziny, jako fundamentu egzystencji człowieka. Wiersze poetki były najczęściej zapisem wewnętrznych przeżyć, dziennikiem duchowym jej serca i umysłu.

Poetka mówi:

nie lituj się nade mną,

znów uśmiecham się

szczęśliwa

i spokojna w swej duszy.

Nie ważne już

Co było ważne kiedyś -

Nie powróci...

$\cdots$

(przekład Autorki) (Wołanie serca 143).

Utwory Jewheniji Żabińskiej przepełniał lęk i pytania natury egzystencjalnej. Autorka porządkowała świat poprzez własną medytację 
filozoficzną. Stawiała niełatwe pytania drugiej osobie, obecnej w jej wierszu, chociaż nie oczekiwała na nie odpowiedzi. Jej pytania osobiste przybierały postać uniwersalnej refleksji o trwaniu wartości ponadczasowych takich jak życie, miłość czy wieczność.

Dla autorki odczucia wewnętrzne czy nastroje duchowe, wtopione były w stany duszy wyrażone symbolicznie. Poprzez poezję autorka mówiła o rzeczach ważnych w jej życiu, o dramacie i rozdarciu serca. Jasno i prosto wypowiadała się również o miłości, która scala życie i pozwala dzielić się radością i nadzieją z drugim człowiekiem. Miłość sprawia łaskę „odświętnego cudu”, jak mówi poetka, w opozycji do codzienności oraz daje moc wędrowania ku przestrzeniom jeszcze nie odkrytym.

Oczekując na twój głos

Wstrzymuję oddech aby umrzeć

W oka mgnieniu

A potem

Znowu zanurzyć się w noc

Zrywając grzech niewoli

Odlecieć jak ptak

Naprzeciw znojom losu

(przekład Jan Leończuk) (Wołanie serca 144).

Twórczość poetycką Jewheniji Żabińskiej dopełniają rozważania o tożsamości narodowej. Na tle ukraińskiej literatury Podlasia rozważania te posiadają własną stylistykę, odnoszącą się do losów zbiorowości wyrażoną pytaniami retorycznymi. Natomiast jej wczesne utwory poetyckie świadczą również o dużym poczuciu wspólnoty losów z ziemią podlaską, krajobrazem rodzinnym a także cerkwią prawosławną.

Wyrazem ciągłości losów literackich i poszukiwań własnej tożsamości ukraińskich poetów podlaskich, jest twórczość najmłodszej autorki Justyny Korolko (rok urodzenia 1982). W twórczości Justyny Korolko, powstającej w języku przodków, czyli jak to określa poetka, w języku „babci Kati Saczko” , uosabia się odnalezienie siebie w rodzinnym dialekcie, mimo, iż Justyna wydała w Krakowie tomik po polsku Nagość nad nagościami i wszystko nagość (2004). Natomiast w 2005 roku ukazał się jej ukraińskojęzyczny tomik Miż zołotom $i$ smertioju, w którym poetka zaproponowała wybór wierszy napisanych gwarą. W 2008 roku poeta Jan Leończuk wydając antologię Wołanie serca, ocenił wiersze poetki jako „zaprzeczenie spróchniałych wiejskich przydomowych ławeczek na których siadywali mieszkający obok siebie ludzie dzieląc się wiadomościami zza horyzontu" (Wołanie serca 148).

Wyrazem głębokiej refleksji w twórczości poetki jest jej kobieca wrażliwość na otaczający świat i poszukiwanie trafnej metafory. Justyna Korolko otwiera się na pytania o sens ponadczasowości życia, stąd w jej twórczości dominują wyznaczniki stanowiące o naturze ludzkiej: intuicja, wzruszenie czy obojętność.

będę zagłębieniem twojej pulsującej dłoni 
która oprze się o moje oczy

by lepiej widzieć

śmiech zauroczy ściany

i usiądzie do fotografii miłosnej

popędzi przez dziurkę od klucza

podziwiany przez uszy konfidentów

przerazi się identyczność chwili

że to początek wszystkiego

będziemy ratować nasze twarze

stojąc na białych i czarnych

płaszczyznach

odbijających słońce

po drugiej stronie róż

aż czas zabulgoce

i nikt nie odda nas śmierci

(przekład Jan Leończuk) (Wołanie serca 81).

Justyna Korolko obdarowana dużą wrażliwością i ekspresją językową, tworzy własny świat przeżyć i narracji literackich. W jej prywatnych wierszach, łączą się hiperboliczność i marzenia, tradycja rodzinna oraz lektury. Poetka wyznaje potrzebę życia poezją, uczenia się jej „na pamięć” oraz identyfikowania się z każdym napisanym słowem.

Lęk i niepokój twórczy w utworach Justyny Korolko, to zapis wewnętrznego dialogu ze sobą, a także porządkowanie ponadczasowych wartości w chaosie i natłoku dziejących się zdarzeń. Zwyciężają emocje i uczucia, stąd poezja autorki wydaje się cenna na tle ukraińskiej poezji Podlasia.

Wnioski i perspektywa badań. Omawiając fenomen literatury ukraińskiej na Podlasiu trzeba stwierdzić, że przeszła ona dużą transformację świadomościową $\mathrm{z}$ pogranicza gwarowego ukraińsko-białoruskiego (lata siedemdziesiąte XX wieku) do własnego ukraińskiego areału językowego, rozwijającego się po 1990 roku. Dotyczy to zwłaszcza twórczości Iwana Kyryziuka, Jurija Hawryluka i Jewheniji Żabińskiej. Jednocześnie dla takich sylwetek pisarskich jak Sofija Saczko czy Justyna Korolko nadal problematyczne pozostaje przeszeregowanie do literatury ukraińskiej lub białoruskiej. Optymalne byłoby stwierdzenie, że obie poetki są częścią składową niszowego dyskursu literackiego podejmowanego ukraińską gwarą okolic Bielska Podlaskiego.

Zastanawiając się nad twórczością pisarzy ukraińskich z Podlasia, należałoby wyrazić ogólną myśl o zbiorowym doświadczeniu słowa, które prowadziło ku literaturze ukraińskiej, bez negacji języka przodków, czyli gwary ukraińskiej Podlasia, jako komunikacji literackiej.

W literaturze ukraińskiej na Podlasiu ważną rolę odegrał redagowany w latach osiemdziesiątych „Nasz Hołos”. Jego treść ukazuje problematykę oraz 
nazwiska pisarzy, którzy nie wyszli poza ówczesne realia rocznika i nie są znani. Pozostawili oni po sobie wiersze pisane ukraińską gwarą podlaską, cenne z punktu widzenia historii literatury na tym terenie i bliskie do poezji ludowej.

Wyrazem poszukiwań twórczych ukraińskiego środowiska pisarskiego na Podlasiu pozostanie ich serdeczny stosunek wobec Białoruskiego Stowarzyszenia Literackiego „Białowieża”, organizacji twórczej z którą niektórzy pisarze ukraińscy Podlasia byli związani oraz łączyły ich przyjazne więzy i gościnny druk, pisanych gwarą ukraińską utworów na łamach białoruskojęzycznej „Niwy”. Są to również wyjazdy poetów ukraińskich do pracowni Włodzimierza Naumiuka, do Kaniuk nad Narwią.

\section{Spis wykorzystanej literatury}

Дуць-Файфер, Олена. «Літературна творчість українців у Польщі після другої світової війни». Slavia Orientalis, cz. 2, t. XLV, 1996, s. 203-20.

Єкатеринчук, Андрій. «Поезії "Нашого голосу" (1983-1988) у вибраному Андрія Єкатеринчука». Український літературний провулок, т. 8, Люблин, 2008, с. 182226.

Занєвська, Тереза. «Очікування на доглибинне слово». Украйнський літературний провулок, т. 6, Люблин, 2006, с. 257-63.

Карабович, Тадеуш. «Літературні псевдоніми в українській літературі УСКТ періоду 1956-1990 рр.». Український літературний провулок, т. 19, Люблин 2019, с. 153-7.

Карабович, Тадеуш. «Між словом і мовчанням. Декілька загальних думок про нашу літературу». Український літературний провулок, т. 10, Люблин, 2010, с. 167-76.

Киризюк, Іван. Моїй Батьківщині. Варшава: Видавництво ГП УСКТ, 1986.

Лесів, Михайло. «Мова віршів підляської поетеси Софії Сачко». Український літературний провулок, т. 12, Люблин, 2012, с. 20.

Лесів, Михайло. «Про українсько-підлясько-холмські вірші Степана Сидорука та їх мовну форму». Український літературний провулок, т. 3, Люблин, 2003, с. 216-22.

Лесів, Михайло. Українські говірки у Польщі. Варшава, 1997.

Ніва: Час і людзі 1956-2006. Беласток, 2006.

Сидорук, Степан. Над Бугом. Варшава: Видавництво ГП УСКТ, 1983.

Столярчук, Богдан. Не наполохай ранню тишу. Рещензії. Рівне-Люблин, 2007.

Яручик, Віктор. «Поняття Батьківщини у творчому дискурсі Івана Киризюка. Декілька штрихів до 70-річчя видатного підляського поета». Український літературний провулок, т. 19, Люблин, 2019, с. 63-9.

Sawicki, Doroteusz. Grabarka. Monaster na Świętej Górze, Białystok, 2007.

Wołanie serca. Antologia poezji ukraińskiej Podlasia, wybór i przekład Jan Leończuk. Białystok, 2008.

Zaniewska, Teresa. Podróż daremna. Szkice o poezji białoruskojęzycznej w Polsce, Białystok, 1992, s. 92-9.

\section{References}

Duts-Faifer, Olena. "Literaturna tvorchist ukraintsiv u Polshchi pislia druhoi svitovoi viiny". Slavia Orientalis, part 2, vol. XLV, 1996, pp. 203-20.

Yekaterynchuk, Andrii. "Poezii "Nashoho holosu" (1983-1988) u vybranomu Andriia Yekaterynchuka". Ukraiński Zaułek Literacki, vol. 8, Liublyn, 2008, pp. 182-226.

Zanievska, Tereza. "Ochikuvannia na dohlybynne slovo". Ukraiński Zaułek Literacki, vol. 6, Liublyn, 2006, pp. 257-63.

Karabovych, Tadeush. "Literaturni psevdonimy v ukrainskii literaturi USKT periodu 19561990 rr.". Ukraiński Zaułek Literacki, vol. 19, Liublyn 2019, pp. 153-7. 
Karabovych, Tadeush. "Mizh slovom i movchanniam. Dekilka zahalnykh dumok pro nashu literaturu”. Ukraiński Zaułek Literacki, vol. 10, Liublyn, 2010, pp. 167-76.

Kyryziuk, Ivan. Moii Batkivshchyni. Varshava: Vydavnytstvo HP USKT, 1986.

Lesiv, Mykhailo. "Mova virshiv pidliaskoi poetesy Sofii Sachko". Ukraiński Zaułek Literacki, vol. 12, Liublyn, 2012, p. 20.

Lesiv, Mykhailo. "Pro ukrainsko-pidliasko-kholmski virshi Stepana Sydoruka ta yikh movnu formu". Ukraiński Zaułek Literacki, vol. 3, Liublyn, 2003, pp. 216-22.

Lesiv, Mykhailo. Ukrainski hovirky u Polshchi. Varshava, 1997.

Niva: Chas i liudzi 1956-2006. Belastok, 2006.

Sydoruk, Stepan. Nad Buhom. Varshava: Vydavnytstvo HP USKT, 1983.

Stoliarchuk, Bohdan. Ne napolokhai ranniu tyshu. Retsenzii. Rivne-Liublyn, 2007.

Yaruchyk, Viktor. "Poniattia Batkivshchyny u tvorchomu dyskursi Ivana Kyryziuka. Dekilka shtrykhiv do 70-richchia vydatnoho pidliaskoho poeta". Ukraiński Zaułek Literacki, vol. 19, Liublyn, 2019, pp. 63-9.

Sawicki, Doroteusz. Grabarka. Monaster na Świętej Górze, Białystok, 2007.

Wołanie serca. Antologia poezji ukraińskiej Podlasia, wybór i przekład Jan Leończuk. Białystok, 2008.

Zaniewska, Teresa. Podróż daremna. Szkice o poezji białoruskojęzycznej w Polsce, Białystok, 1992, pp. 92-9. 